\title{
TAX TREATMENT OF "LESSORS" AND "LESSEES" UNDER LEASE-PURCHASE AGREEMENTS:
}

Tне Internal Revenue Code treats differently business rental payments and payments made pursuant to a purchase of depreciable business property. The lessee may deduct rent as a business expense under Section 23(a) (1) (A). ${ }^{1}$ But this section forbids deduction when the taxpayer is "taling title" or has an "equity" in the property. Instead, he usually may depreciate the property." On the other hand, the lessur reports rent as ordinary incunte, and he may take depreciation deductions." If payments are received as part of a "sale or exchange" of his property, the taxpayer cannot deduct depreciation, but his "gain" may be taxable at the lower capital gains rates under Section $117(\mathrm{j}) .^{\mathrm{s}}$

Courts are forced to apply the Code's rent-purchase distinctions to contracts which use "lease" form and terminology but give the lessee an option to buy

* Benton v. Commissioner, 197 F.2d 745 (5th Cir. 1952).

1. "In computing net income there shall be allowed as deductions ... all the ordinary and necessary expenses paid or incurred during the tassble year in carrying on any trade or business, including . . . rentals or other payments rcquircd to be made as a condition to the continued use or possession, for the purposes of the trade or business, of property to which the taxpayer has not talien or is not taling title or in which

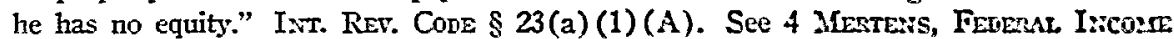

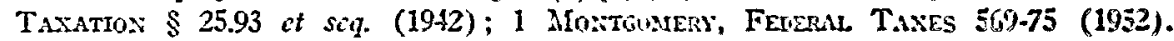

2. INT. Rev. CODE $\$ 23$ (1) (1). Under an executory contract of sale, before legal title has passed, the vendee may talke a depreciation deduction if he is in possession of the property and "assumes the burdens of ownership." I.T. 2275, V-1 Cu21. EuLL 62, 63 (1926). See also 4 Mertens, Federil Incosie Tasation $\$ \$ 23.0 j, 23.11$ (1942); Chicago-Stoker Corp., 14 T.C. 441, 44 (1950); Judson Mills, 11 T.C. 25, 30 (1948). Although "rentals" which are not deductible under $\$ 23(a)(1)(A)$ may be added to the property's $\$ 113$ adjusted basis and deducted later as depreciation, the larger immediate rent deduction would seem more desirable to most lessees under lease-purchase agrcements.

3. InT. ReV, CODE $\$ 22(a)$.

4. INT. Rer. Cone \$ 23(1) (1).

5. Depreciable or real property used in trade or business is prcoludcd from copital gains treatment under $\$ 117$ (a). But a gain frum the sale or cxchange of stech property, if held more than six months, is taxable under $\$ 117(j)$ at the long term capital gain rates if the aggregate of " 117 ( $j$ ) transactions" for the year is a net gain.

Section 23(1) allows a depreciation deduction for property used in trade or business or "held" for the production of income. Generally, depreciation is allowed to the party who will suffer economic loss by a dedine in value. The legal owner usually meets this test. See 2 P-H 1952 FED. TAX SERv. If 14,030, and cases citcd therein. Eut the criterion of "holding the property" also permits the vendee under installment or conditional sales contracts to take depreciation. See I.T. 2275, V-1 Cux. BuLI. 62 (1925); 1 Mo:itGONERY, FenERAL TAXES 917-18 (1952). 
the property. ${ }^{6}$ In some cases, the contract's purpose is clear and the tax consequences are well settled. If the lessee is obligated to pay rent for the entire term and may take title after all payments are completed without paying an additional sum, the lease is actually a disguised conditional sale ; both lessee and lessor thus report the periodic payments as part of the purchase price. ${ }^{8}$ But variations of two other types of lease-purchase agreements have caused much confusion. ${ }^{9}$ The first is similar to the disguised conditional sale except that the lessee is not legally bound to make all the payments; he

6. Motives for adopting the lease-option form vary. This device affords the prospective purchaser a means of testing the property before promising to buy. It assures him the full benefit of costly improvements and of favorable fluctuations in the price level. For these purposes the lease-option agreement is a useful commercial device. On the other hand, vendor and purchaser may desire to escape local taxes, Robert A. Taft, 27 B.T.A. 808 (1933) (lease option form adopted to avoid high tax on purchase moncy mortgages); or to circumvent statutory regulation of installment sales, William A. McWaters, P-H 1950 TC MEN. DEc. If 50,152 (1950) (minimum down-payment requirements) ; E. G. Robertson, 19 B.T.A. 534 (1930) (redemption statutes which delay vendor's repossession after a default).

Income tax avoidance may also be sought. Lessee may wish to amortize a down payment, Robert A. Taft, supra; or depreciate improvements over a relatively short lease term, Rankin v. Commissioner, $60 \mathrm{~F} .2 \mathrm{~d} 76$ (6th Cir. 1932); or deduct rentals as a busincss expense, Jefferson Gas Coal Co. v. Commissioner, 52 F.2d 120 (3d Cir. 1931). Lessor may wish to avoid an immediate tax on his gain from the sale, A.R.M. 189, I-2 CuM. Burl 68 (1922). For a short discussion of lease-option income tax treatment, sec Siegel, Options to Buy or Renew Contained in a Lease in ProceEdings of N.Y.U. 6TH ANN. Institute on Federal Taxation 990 (1948). See also 4 Mertens, Federal Incone TAXATION $\$ 25.93 n .24$ (1942); 4 id. at 417 (Cum. Supp. 1952); 26 TAxEs 741 (1938); 1 P-H 1952 Fed. TAX SERV. If 12,020 et seq.

7. "We agree with The Board [of Tax Appeals] that the provisions in the agreement, that when the annual royalties amounting to $\$ 310,000$ had been paid, the [lessors] were to execute and deliver a deed in fee simple for all unmined coal and that the petitioner was compelled to pay the $\$ 310,000$ within the ten years . . . , are entirely foreign to an actual, bona fide lease and show the true nature of the agreement to be a contract of sale rather than a lease." Jefferson Gas Coal Co. v. Commissioner, 52 F.2d 120, 122 (3d Cir. 1931). Cf. Watson v. Commissioner, 62 F.2d 35, 36 (9th Cir. 1932). For the definition of a conditional sale and its "lease" counterpart, see 2 UNIFORM LAWS Annotated: Conditional Sales $\S 1$, Commissioners' Note (1922). Sec also 2 Willuiston, Sales $\$ 336$ (rev. ed. 1948); 3 Jones, Chattey Mortgages and Conditional Sales $\S 958$ (Bowers' ed. 1933).

8. Watson v. Commissioner, 62 F.2d 35 (9th Cir. 1932) (lessor) ; Jefferson Gas Coal Co. v. Commissioner, 52 F.2d 120 (3d Cir. 1931) (lessee) ; Hesler Machine \& Marine Works, Inc., 39 B.T.A. 644 (1939) (lessee); Alexander W. Smith, Jr., 20 B.T.A. 27 (1930) (lessor and lessee); E. G. Robertson, 19 B.T.A. 534 (1930) (lessor).

9. "Cases like this, where payments at the time they are made have dual potentialities, i.e., they may turn out to be payments of purchase price, or rent for the use of property, have always been difficult to catalogue for income tax purposes." Chicago-Stoker Corp., 14 T.C. 441,444 (1950). For differences between the disguised conditional sale and other leasepurchase agreements, see 2 Wilisiston, Sales $\$ 336$, p. 298 (rev. ed. 1948); 3 JoNes, Chatted Mortgages and Conditional Sales $\$ \S 952-63$ (Bowers' ed. 1933); Eacer, Chattel Mortgages and Conditional Sales $\$ \S 303-05$ (1941). 
has the option of withdrawing at any time during the lease term. ${ }^{10}$ Often, such contracts permit the lessee to acquire title early by a lump-sum payment of the remaining rentals. ${ }^{11}$ The second lease-purchase type binds the lessee to pay rent and gives him an option to purchase at the end of the lease for a fixed sum. ${ }^{12}$ Sometimes the lessee can pay the option-price during the term and take title, thereby avoiding the balance of the rentals. ${ }^{13}$

Courts initially looked to the parties' intent in order to determine whether a lease-purchase agreement constituted a sale. ${ }^{14}$ Courts presumed that the lessee intended to purchase when rentals exceeded fair rental value ${ }^{15}$ or an option-price was below the property's worth. ${ }^{16}$ Other evidence of lessee's intent to purchase included: expensive improvements; ${ }^{17}$ lessor's placing the deed in escrow ${ }^{18}$ inconsistency of lessor's tax treatment with lessee's claim. ${ }^{10}$ But economic data and other indicia of intent were usually ignored by courts

10. Title passes under such contracts when rentals paid equal the pre-fixed price for the property. Rotorite Corp., 40 B.T.A. 1304 (1939), reid, 117 F.2d 245 (7th Cir. 1941); Chicago-Stoker Corp., 14 T.C. 441 (1950); Truman Bowen, 12 T.C. 446 (1949); Mary Alice Browning, P-H 1950 TC MEar. DEC. \ 50,285 (1950).

11. See cases cited in note 10 silpra.

12. E.g., Benton v. Commissioner, 197 F.2d 745 (5th Cir. 1952); Edward E Haverstick, 13 B.T.A. 837 (1928); Holeproof Hosiery Co., 11 B.T.A. 547 (1923). Purchase may be encouraged by a small option-price relative to the property's value. If so, rentals undoubtedly would include part of the purchase price Similarly, part of the rent may be consideration for the option privilege itself. Lessee's option is "true" only when the option price accurately reflects the property's estimated future worth, with rental payments exclusively for the present use of the property. Theoretically, such an option would have no monetary value at the time of contracting. It may acquire a positive worth during the lease term because of a general price rise or improvements added by lessee. But ownership of a valuable option by itself does not give the holder a "legal" property interest. Helvering v. San Joaquin Fruit \& Invest. Co, 297 U.S. 496 (1936).

13. E.g., Gilken Corp., 10 T.C. 445 (1948); Helen E. Leatherbee, 34 B.T.A. 196 (1936).

14. Watson v. Commissioner, 62 F.2d 35, 36 (9th Cir. 1932) (lessor); Jefferson Gas Coal Co. v. Commissioner, 52 F.2d 120, 122 (3d Cir. 1931) (lessce); Robert A. Taft, 27 B.T.A. S08, 811 (1933) (lessee); Alexander W. Smith, Jr., 20 B.T.A. 27, 32 (1930) (lessee and lessor) ; E. G. Robertson, 19 B.T.A. 534, 540 (1930) (lessor). The intent criterion was brought into the tax field from other areas of the law where it had bren used to determine whether a lease-option contract was a lease or conditional sale. See, e.g., Hervey v. Rhode Island Locomotive works, 93 U.S. 664 (1876) (creditors' dispute after lessee's bankruptcy), cited in Benton v. Commissioner, 197 F.2d 745, 752 n.5 (5th Cir. 1952).

15. E.g., Holeproof Hosiery Co., 11 B.T.A. 547, 556 (1923).

16. E.g., Alevander W. Smith, Jr., 20 B.T.A. 27, 32 (1930). Courts also considered: the size of the initial "rental" payment relative to the total consideration necessary to buy the property, Robert A. Taft, 27 B.T.A. S0S, $\$ 12$ (1933); Steve Lodzieski, P-H 1944 TC MIEas. DEC. If 44,326, p. 1171 (1944); whether or not rentals vere to be credited against a purchase price, Goldfields of America, Ltd, 44 B.T.A. 200, 201 (1941).

17. Rankin v. Commissioner, 60 F.d 76, 77 (6th Cir. 1932).

18. Alexander W. Smith, Jr., 20 B.T.A. 27, 32-3 (1930).

19. William A. McWalters, P-H 1950 TC MEas. Dec I 50,152, p. 484 (1950). 
when ruling on lessor's tax treatment of the rentals. Payments were part of purchase price and therefore entitled to capital gains treatment by the lessor only when his lessee was legally bound to consummate the sale. ${ }^{20}$ Under all other leases, payments were ordinary income until exercise of the option to purchase. ${ }^{21}$ Thus, under the same lease-purchase agreements, payments might be purchase price to lessee and rent to lessor. ${ }^{22}$

To provide a "fixed rule for guidance of taxpayers and the Commissioner,"23 the Tax Court in 1948 abandoned "intent" in favor of a straight economic test. $^{24}$ When periodic payments exceeded fair rental value ${ }^{25}$ or an option-

20. Watson v. Commissioner, 62 F.2d 35 (9th Cir. 1932); Alexander W. Smith, Jr, 20 B.T.A. 27 (1930); I.T. 1819, II-2 Cum. Bur.m 73 (1923). See 2 Unirorn Laws, Annotated: Conditional Sales $\$ 1$, Commissioners' Note (1922). Courts recited cconomic data and other indicia of intent in lessor cases only when the lessee was legally bound to make all payments. The Watson and Smith cases are good examples of how courts used intent evidence to buttress their findings of a conditional sale. Yet when lessor's tenant was not legally bound, intent evidence was overlooked. See cases cited in note 21 infra.

21. "That the amounts fixed as monthly payment may have been larger than would otherwise have been collected as rent, may be true, but ... where the payments created no equity for the lessee under the terms of the instruments, we must hold that tho [Commissioner] correctly added the amounts received to the petitioner's [ordinary] income." Edward E. Haverstick, 13 B.T.A. 837, 839 (1928) (emphasis added). Accord, A. W. Henn, 20 B.T.A. 1133 (1930).

Exercise of the option binds vendee to pay the balance of the price and converts the transaction into an outright or conditional sale. Payments received prior to the exercise of the option were treated as ordinary income. Estate of Clarence B. Eaton, 10 T.C. 869 (1948) ; Indian Creek Coal \& Coke Co., 23 B.T.A. 950 (1931). But cf. Rotorite Corp. v. Commissioner, 117 F.2d 245 (7th Cir. 1941) (option exercised in middle of tax year; court permits vendor to report all payments for that year as purchase price).

The closing date of the sale, not the date of option-exercise, determined the year in which the vendor reported his gain or loss. Lucas v. North Texas Lumber Co., 281 U.S. 11 (1930). See Young, Tax Problems int Real Estate Transactions, [1949] U. or ILL. L. FORUM 473.

22. "Since tax deductions by the buyer are controlled by the language of the deduction provision of the statute $[\S 23(a)(1)(A)]$, there is no necessary reciprocal relation between them and the taxation of the periodic payments received by him. ..." Goldficlds of America, Ltd., 44 B.T.A. 200, 202 (1941). However, courts occasionally chafed at the Commissioner's inconsistent treatment of the two parties to the same agrecment. Sec Rotorite Corp. v. Commissioner, 117 F.2d 245, 247 (7th Cir. 1941). In one case, the Commissioner brought lessor and lessee together before the Tax Court to resolve the inconsistency in their treatment of the periodic payments. Alexander W. Smith, Jr, 20 B.T.A. 27 (1930).

23. Chicago-Stoker Corp., 14 T.C. 441, 444 (1950).

24. "[I]t matters not whether the contract was in the form of a lease or a conditional sale, or what was the intention of the parties; if, under the terms of the contracts by which the payments were made, the petitioner acquired an equity in the machinery, which we so find, the payments would not be deductible, due to the limitation prescribed in the code." Judson Mills, 11 T.C. 25, 32 (1948) (emphasis added).

25. Id. at 33 . 
price was below a reasonable estimate of the property's future worth, ${ }^{20}$ lessee acquired an "equity," losing his Section 23(a) (1)(A) rent deduction. Although the economic test was originally applied in lesser cases, the Tax Cuurt by 1950 was also using it to measure the lessor's tax liahility:-2 Lessur cuulu treat the payments as purchase price if they would not lit derluctible as rent by his lessee.28 For the first time, therefore, lessors could receive capital gains treatment for income under a lease which did not hind the lessee to malse all payments.

In the first appellate court challenge to the new Tax Court alpruad, Benton v. Commissioner, ${ }^{29}$ a lessee case, the Fifth Circuit rejected the economic test in faror of the pre-1948 "intent" criterion. Taxpayer was lessee of a taxicab business for ten months during 1945-10. His monthly rental was $\$ 5,000$, and he had an option to purchase fur $\$ 35,000$ at the end of the lease period. Lessor, a partnership, had purchased the company only one year before granting the lease and during that year had earned over $\$ 50,000$ on an investment of $\$ 60,000$. When the lease expired, taxpayer exercised his option to purchase. The Tax Court affirmed the Commissioner's disallowance of the taxpayer's Section 23(a) (1) (A) rent deduction." The court, applying the economic test, found the option-price far helow the property's value and concluded that the rentals were disguised payments of purchase price. In reversing, the Fifth Circuit held that the proper test of taxpayer's right to the deduction was whether the parties intended a lease or conditional sale. Although economic factors were admittedly relevant, the court felt bound to consider all circumstances bearing on the parties' intent. In finding that nu sale was intended, the court noted that lessor had been listed as wwer of the company on the "assumed name" records of the county, while taspayer was listed as manager in the "City directory." Also, the mu-t active partner (in lessor) kept in "close touch" with the business during the lease term and reported the rentals as ordinary income on his tax returns. Furthermore, the court was apparently not convinced that, as of the time of contracting, $\$ 35,000$

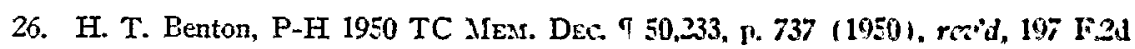
745 (5th Cir. 1952).

27. The "transitional" case was Truman Bowen, 12 T.C. 46 (1949). Although the court referred to the parties' intent, id. at $760-1$, the econonic test seemed decisive. Id. at 463-4. And the authority relied on by the court was the 1948 lessee case (Jtddson Irills) that advanced the economic test. Ibid. Following Bow'n, two cases ignored the parties" intent. Mary Alice Browning, P-H 1950 TC MExr. DEs. T 50,285 (1950); Renner \& Maras, Inc, P-H 1950 TC MEar. DEC. $\uparrow 50,139$ (1950). Two recent cases, however, again mention the parties' intent. W. H. Hughes, P-H 1952 TC Mes. DEc. ๆ \$2,240 (1952) ; L. M. Graves, P-H 1952 TC MEAX. DeC \I 52,143 (1952).

2s. Mary Alice Erowning, P-H 1950 TC MIEar. Dec. T 50,255, y. 955 (1950); Renner \& Maras, Inc., P-H 1950 TC MEar. DEc. if $50,13 \%$, p. 423 (1950). For the time when the payments may be taxed, see notes 41 and 42 infra and accompanying text.

29. 197 F.2d 745 (5th Cir. 1952).

30. H. T. Benton, P-H 1950 TC Mear. Dec. I 50,223 (1950). 
was an unreasonable estimate of what the company would be worth after the ten-month period. The end of World War II was approaching and with it the need for additional expenditures to replace worn-out cabs and the prospect of a decline in the volume of business.

Benton's restoration of the intent test seems unwise on policy grounds and unwarranted by the Code. The test may revive much of the pre-1948 uncertainty over lessee's right to a rent deduction. While the economic test confines serious argument to questions of fair rental value and the property's prospective worth, all circumstances surrounding the transaction must now be considered. True, most courts may decide cases on the basis of economic data, despite verbal adherence to the intent formula and recitations of supporting evidence. ${ }^{31}$ But predicting what facts less perceptive courts will give decisive weight may be impossible. Hence, the intent test might breed litigation, as evidenced by the numerous pre-1948 lease-purchase agreements involved in rent deduction cases. Furthermore, the intent test may result in deductions seemingly not contemplated by Section 23(a)(1)(A). The section bars a rent deduction when lessee has an "equity" or is "taking title." Lessee has an "equity," unless the word is meaningless, regardless of his intent so long as his payments reduce the price he would otherwise have to pay to buy the property. ${ }^{32}$ In Benton, it is difficult to see how lessee did not have an "equity" since his option-price was set at little more than half what lessor had paid for the company one year earlier. And if, as the Fifth Circuit suggested, $\$ 35,000$ was not an unreasonably low estimate of the company's future worth, then a $\$ 50,000$ rental for the ten-month period would be exorbitant unless taxicab businesses depreciate at an extraordinarily rapid rate.

Since the Tax Court had relied on lessee cases to support its application of the economic test to lessors, ${ }^{33}$ Benton also undercuts the more recent lessor tax treatment. If courts now apply a broad intent formula to lessors, ${ }^{34}$ then the same inducements to litigation will exist here as in lessee cases. However, courts may revert to their old lessor intent test, under which rentals were purchase price only if the lessee was legally bound to make all the payments ${ }^{\text {d5 }}$

31. See W. H. Fughes, P-H 1952 TC MEN. DEC. If 52,240 (1952) (decision rendercd six weeks after Benton). Cf. Truman Bowen, 12 T.C. 446 (1949). Tax Court findings of fact, including a finding of "intent," have the same presumptive validity upon review, INT. REv. CODE $\$ 1141$ (a), as do findings of fact by the Federal district courts. FED. R. CIv. P. 52(a). See note 27 supra.

32. "Petitioners assert that the option to purchase was not exercised and this indicates that petitioner had no equity in the property. It is the existence of the equity rather than its acquirement which determines the applicability of the Code's provisions." H. T. Benton, P-H 1950 TC Mear. Dec. If 50,223, p. 739 (1950), rev'd, 197 F.2d 745 (5th Cir. 1952).

33. See note 27 stura.

34. See note 27 supra. W. H. Hughes, P-H 1952 TC Mens. Dec. \ 52,240 (1952) was decided six weeks after Benton. Without citing Benton, the court referred to various indicia of intent, $i d$. at 708, with economic data perhaps decisive. Cf. L. M. Graves, P-H 1952 TC MLEM. Dec. \I 52,143, p. 431 (1952).

35. See cases cited in note 8 supra. 
Under all other leases, lessor's receipts before option-exercise would be ordinary income. But this seems unfair. When payments exceed fair rental, lessor must pay an ordinary income tax on money which may turn out to have been part of the purchase price. Thus if payments after the option is exercised equal or exceed the property's adjusted basis, all or part of the lessor's actual profit on the sale will have been taxed as ordinary income rather than as a capital gain under Section $117(\mathrm{j})$. On the other hand, if the adjusted basis exceeds the payments received after exercise of the option, the resulting loss ${ }^{36}$ may or may not be useful to the lessor, depending upon his income in the taxable year and in other years to which unused portions of the loss may be carried. ${ }^{37}$ And even if the lessor can use his entireloss to offset ordinary income, he will still suffer if the total payments (regardless of when received) allocable to purchase price exceed the adjusted basis; his entire profit will have been taxed as ordinary income. ${ }^{38}$

On the other hand, capital gains treatment of all lessor's receipts is unduly favorable, regardless of the test used by the courts. In part, lessee's payments are for the present use of the property, rightfully allocable to rent.00 The payments may be accurately labeled purchase price only to the extent that they exceed fair rent, giving the lessee a financial stake in the useful life of the property beyond the lease term. ${ }^{40}$ Capital gains treatment of the entire payments ignores their dual function and prefers this taxpayer over the lessor who rents at fair rental value and whose option-price accurately reflects the property's estimated worth. MIoreover, lessor might be able to postpone realization of any taxable income, and liability for taxes, until his receipts

36. Whether it will be an ordinary or capital loss depends on the result of the $\$ 117(j)$ "hodge-podge." See note 5 supra. Section 117 (j) losses can be deducted from ordinary income only to the extent such losses exceed the gain from $\$ 117(j)$ trancactions in the taxable year.

37. See INT. REv. Cone $\$ 122$ (operating loss carry-over). But cf. Lazier v. United States, 170 F.2d 519 (Sth Cir. 194S).

3S. To illustrate: assume that the property's $\S 113$ adjusted basis is $\$ 75$ on January 1 , and a depreciation deduction of \$15 may be taken over the next ten months. The basis after the ten months will thus be $\$ 60$. Taxpayer leases the property at $\$ 20$ for the period (fair rental value) with an option to purchase for $\$ 100$ (estimated marlst value). His net ordinary (rental) income will be $\$ 5$, and, when the option is exercised, he will have a $\$ 40$ capital gain. But if taxpayer leases for $\$ 0$ with an option-price of $\$ 50$, he will have ordinary (rental) income of $\$ 55$ (rent of $\$ 70$ less $\$ 15$ of depreciation) and an offsetting ordinary loss-assuming no other transactions under $\$ 117(\mathrm{j}) \rightarrow$ of $\$ 10$ (selling price of $\$ 50$ less basis of $\$ 60)$, or net income of $\$ 45$. As a result, his $\$ 40$ profit on the sale is taxed at ordinary rates.

39. See Benhasi \& Lutz, Econoxics 17 (1941); Blodgetr, Prrizctrles of Econiosics 343 (rev. ed. 1946).

40. See Fetter, Panctiles of Econorics 122 (1905); Blorgett, Pranctrles of EcoNonitcs 344 (rev. ed. 1946) ; Hicks \& HakT, The Soctal Frasuewost or THE Aurmicasi EcoNonsy 153 n.S (1945). 
exceed the property's basis. ${ }^{41} \mathrm{He}$ thus enjoys the use of the money allocable to rent, unreduced by any tax, until that later date. Lessor's net benefit, therefore, is the tax saving on the "rent" plus the interest on the money that normally would have been paid earlier in taxes.

The shortcomings of both straight ordinary income or capital gains treatment suggest that an allocation of payments between rent and purchase price would be the most appropriate method of taxing the lessor. That portion of a payment attributable to rent should be included in ordinary income, any excess reported as purchase price. Also, the lessor, as well as the lessee, should be permitted to take depreciation deductions. This approach would neither penalize nor reward the lessor; his tax bill would be computed on the basis of fair rental value and a "true" option-price. And to the extent that lessor does receive purchase price, he has the choice of recognizing his gain when such receipts exceed the property's basis or reporting income by the installment method. ${ }^{42}$ Moreover, allocation should be made as of the time of contracting, grounded on estimates of fair rent and the future value of the property. ${ }^{43}$ Otherwise, fluctuations in economic conditions and the price level might lead to multiple reallocations, an unnecessary administrative burden. Although allocation would be equally desirable for lessees, the wording of Section 23(a) (1) (A), unchanged since $1916,{ }^{44}$ precludes such treatment.

Retention of the economic test is a prerequisite to an allocation procedure. By definition, the test is concerned with the real economic function of the

41. Truman Bowen, 12 T.C. 446, 466-7 (1949). See 1 Montgonery, FederAt TAxes 56-7 (1952). For tax treatment of lessor if lessee fails to exercise his option, sec Renner \& Maras, Inc., P-H 1950 TC MeM. Dec. $\int 50,139$ (1950). However, it seems unlikely that many lessees will fail to purchase if their payments exceed fair rental value. Once lessee pays a substantial portion of the "rentals," he would benefit by acquiring the property even if only to resell; a resale might enable him to recoup at least part of the past payments attributable to purchase price which he would otherwise forfeit. See Chicago-Stoker Corp. v. Commissioner, 14 T.C. 441 (1950).

42. Truman Bowen, 12 T.C. 446,467 (1949). In Boreen, the Commissioner unsuccessfully sought to impose the installment method on the lessor. Cf. L. M. Graves, P-H 1952 TC Mear. Dec. $\| 52,143$ (1952). Permitting the lessor to defer recognition of gain until purchase price receipts exceed the property's basis favors him, since he has the use of the purchase money-unreduced by a tax-until the basis is exceeded or lessee declines the option. See Renner \& Maras, Inc., P-H 1950 TC Men. DEc. If 50,139 (1950) (lessce declined option). Because an allocation procedure would deny lessors the broader tax advantages previously enjoyed, the Commissioner may no longer be anxious to require reporting by the installment method. For the mechanics of the installment method, see INT. Rev. Code § 44; U.S. Treas. Reg. 111, § 29.44-1 (1943); 1 P-H 1952 Fed. TAx SERv. II 6665 (1952).

43. Under the economic test, fair rental value and the property's worth at the end of the lease term must be estimated as of the time of contracting. Benton v. Commissioner, 197 F.2d 745, 752 (5th Cir. 1952).

44. The Revenue Act of 1913, 38 Star. 114, 167, 172 (1913), provided for a rental deduction; the present language of $\S 23$ (a) (1) (A) was substituted by $\S 12$ (a) of the 1916 Act, 39 StAт. 756, 767 (1916). See note 1 supra. 
lease-purchase payment. The intent test, on the other hand, seeks only to affix the categorical label of "sale" or "no sale,"sis distorting the hybrid nature of the contract. Furthermore, the Commissioner and courts must be willing to assume the burden of computing a reasonable estimate of the property's rental and future value. ${ }^{46}$ The necessary computations are no more difficult than allocations now required under other sections of the Code.iz And fairly simple devices are available to minimize the threat of groundless claims to an allocation. ${ }^{48}$

45. Benton v. Commissioner, 197 F.2d 745, 752 (5th Cir. 1952).

76. Courts have been reluctant to allocate for the parties under lease-purchase agresments. See, e.g., Edward E. Haverstich, 13 B.T.A. \$37, 839 (1923).

47. E.g., INT. Rev. Code \$ 45. See, generally, 3 P-H 1952 Fed. Tax Senv. 2 29,017.

48. Whenever a lessor allocates, the Commissioner should inspect the lessee's return. If the lessee does not claim a rent deduetion for the payments he makes under the leasepurchase agreement, the Commissioner's primary concern will then be with the reasonableness of the lessor's allocation. However, if the lessee dues claim a rent deduction, the Commissioner should challenge both the lessee's and the lessor's return. In effect, the lessee rather than the Commissioner can be made the lessor's adverse party. Cf. Alesandur W. Smith, Jr., 20 B.T.A. 27 (1930). Tax avoidance thruugh an alloeation of yayments received under a lease-purchase agreement would probably be unattractive to normally responsible businessmen who know that part of the price will be litigation, with their lessees as adverse yarties. 